\title{
The Role of Primary Care Physicians and Reminder Systems in Increasing Colorectal Screening Recommendation [Letter]
}

This article was published in the following Dove Press journal:

Advances in Medical Education and Practice

\author{
Daniel Campioni-Norman (D) ${ }^{\prime}$ \\ Anthony Rayner ${ }^{2}$ \\ 'Imperial College London, London, UK \\ ${ }^{2}$ Wexham Park Hospital, Wexham, UK
}

\section{Dear editor}

We read with great interest the original research article "Knowledge, Attitude and Practice of Physicians Regarding Screening of Colorectal Cancer in Qatar: A CrossSectional Survey". ${ }^{1}$ As practicing surgeons in the UK, it was interesting to consider whether the poor compliance and recommendation is actually to be expected from internal medicine physicians?

It has been recognised across Europe that primary care physicians hold an important role in screening of colorectal cancer, but they have a changing role due to the introduction of population based screening programmes. Their role is now far more supportive and informative, facilitating the screening opposed to implementing. Qatar similarly has a population based screening programme, where patients are contacted via telephone. ${ }^{2}$

Hospital physicians in the UK would seldom be involved with screening uptake in asymptomatic patients, due to limited time and priority of acute pathologies. This is mirrored in this author's study results. It would be interesting to extend the study to primary care physicians to see if they have increased compliance and recommendation versus their internal medicine counterparts, given in the UK this is where we would expect to see improved results.

Secondly, previous similar studies frequently found forgetfulness to be a common reason for poor recommendation rates, a reason not explored in the author's survey. Subsequent meta-analysis found physician-targeted reminder systems to be a simple cost effective method to increase uptake and recommendation. ${ }^{3}$ This simple intervention could be utilised in Qatar's current electronic healthcare programme.

\section{Disclosure}

The authors report no conflicts of interest in this communication.

\section{References}

1. Mahmoud M, Parambil J, Danjuma M. Knowledge, attitude and practice of physicians regarding screening of colorectal cancer in qatar: a cross-sectional survey. Adv Med Educ Pract. 2020;11:843-850. doi:10.2147/AMEP.S268315
Correspondence: Daniel Campioni-

Norman

Imperial College London, Sir Alexander Fleming Building, Imperial College Road

London SW7 2AZ, UK

Tel +447967863673

Email dlc12@ic.ac.uk
Advances in Medical Education and Practice 2021:12 107-108 
2. National Cancer Programme Qatar. Guidelines for colorectal cancer screening. Available from: https://www.moph.gov.qa/Admin/Lists/ PublicationsAttachments/Attachments/20/Guidelines\%20for\% 20Colorectal\%20Cancer\%20Screening\%20V1.2015.pdf. Accessed November 12, 2020.
3. Triantafillidis JK, Vagianos C, Gikas A, Korontzi M, Papalois A. Screening for colorectal cancer: the role of the primary care physician. Eur J Gastroenterol Hepatol. 2017;29(1):e1-e7. doi:10.1097/MEG.0000000000000759

Dove Medical Press encourages responsible, free and frank academic debate. The content of the Advances in Medical Education and Practice 'letters to the editor' section does not necessarily represent the views of Dove Medical Press, its officers, agents, employees, related entities or the Advances in Medical Education and Practice editors. While all reasonable steps have been taken to confirm the content of each letter, Dove Medical Press accepts no liability in respect of the content of any letter, nor is it responsible for the content and accuracy of any letter to the editor.

\section{Publish your work in this journal}

Advances in Medical Education and Practice is an international, peerreviewed, open access journal that aims to present and publish research on Medical Education covering medical, dental, nursing and allied health care professional education. The journal covers undergraduate education, postgraduate training and continuing medical education including emerging trends and innovative models linking education, research, and health care services. The manuscript management system is completely online and includes a very quick and fair peer-review system. Visit http://www.dovepress.com/testimonials.php to read real quotes from published authors. 